\title{
PARTICLE SWARM OPTIMIZATION OF WIND FARM DUE TO NON-GREENHOUSE GAS EMISSION UNDER POWER MARKET CONSIDERING UNCERTAINTY OF WIND SPEED USING MONTE CARLO METHOD
}

\author{
Mohammad Mohammadi, Hossein Nasiraghdam
}

Original scientific paper In this study a multi-objective formulation for optimal sizing and finally optimal operation of wind farm in distribution systems for maximizing net present worth of system is analysed. The proposed system in this study consists of upstream network i.e. $63 \mathrm{kV} / 20 \mathrm{kV}$ substation as main grid and wind turbines as DG to supply load. In this study, total net present worth as objective function consists of two parts including net present worth of distribution company (Disco) and of wind farm owner (WT-owner). In order to obtain accurate results, in this study, the uncertainty of wind speed is considered using the Monte Carlo method. The implemented technique is based on particle swarm optimization method (PSO) and weighting coefficient method. Simulation results on 33-bus distribution test system under power market operation are presented to show the effectiveness of the proposed procedure. The considered objective function is of highly non-convex manner, and also has several constraints. On the other hand due to significant computational time reduction and faster convergence of PSO in comparison with other intelligent optimization approaches such as Genetic Algorithm (GA) and Artificial Bee Colony (ABC) the simple version of PSO has been implemented. Of course other versions of PSO such as Adaptive PSO and combination of PSO with other methods due to complexity of this optimization problem have not been considered in this research.

Keywords: electricity market; Monte Carlo; particle swarm optimization; wind farm

Optimizacija roja čestica vjetroelektrane zbog ispuštanja ne-stakleničkih plinova na tržištu električne energije uzimajući u obzir nesigurnost brzine vjetra primjenim Monte Carlo metode

Izvorni znanstveni članak U ovom se radu analizira formulacija s više ciljeva za optimalnu veličinu i konačno optimalno funkcioniranje vjetroelektrane u distribucijskim sustavima za postizanje maksimalne neto sadašnje vrijednosti sustava. Sustav predložen u ovom radu sastoji se od mreže suprotnog toka struje, odnosno trafostanice $63 \mathrm{kV} / 20 \mathrm{kV}$ kao glavne mreže i vjetroturbina kao DG za napajanje. U ovom radu, ukupna neto sadašnja vrijednost kao funkcija cilja sastoji se od dva dijela, uključujući neto sadašnju vrijednost distribucijske kompanije (Disco) i vlasnika vjetroelektrane (WT-owner). U svrhu dobivanja točnih rezultata, u ovom se radu nesigurnost brzine vjetra razmatra primjenom Monte Carlo metode. Primijenjena se tehnika zasniva na metodi optimizacije roja čestica (PSO) i metodi težinskog koeficijenta. Rezultati simulacije na sustavu ispitivanja distribucije energije na tržište iz 33 sabirnice daju se u svrhu pokazivanja učinkovitosti predloženog postupka. Razmatrana funkcija cilja je krajnje ne-konveksnog načina i također ima nekoliko ograničenja. S druge strane, zbog značajnog smanjenja vremena izračuna i brže konvergencije PSO-a u usporedbi s drugim inteligentnim pristupima optimizacije kao što su Genetic Algorithm (GA) and Artificial Bee Colony (ABC), primijenjena je jednostavna verzija PSOa. Naravno, druge verzije PSOa kao što su Adaptive PSO i kombinacija PSO s drugim metodama, zbog složenosti tog problema optimizacije, nisu uzete u obzir u ovom istraživanju.

Ključne riječi: Monte Carlo; optimizacija roja čestica; tržište električnom energijom; vjetroelektrana

\section{Introduction}

The greenhouse gas emission of electric power sectors around the world is about $1 / 3$ of the total world emission, indicating the significance of electric power sectors in the global warming issue. In recent years, climate change due to greenhouse gas emissions has become a focus of international organizations and governments. In order to reduce greenhouse gas emissions, the aim has been placed on finding more environmentally friendly alternatives for electricity power generation. Renewable energy technologies may include solar energy, wind, fuel cells, micro-turbines, etc. Due to advances in wind energy technologies, wind power is currently considered one of the most rapidly increasing resources. There is no doubt that the benefit of WTs is beginning to attract many utilities in the electricity market [1].

There are several market models and transactions to achieve a competitive electricity environment. Three basic models based on types of transactions are: pool model, bilateral contract model and hybrid market model. A pool market is a centralized market place that clears the market for the buyers and sellers. Electric power sellers/buyers submit bids to the pool for the value of power that they desire to trade in the market $[1,2]$. In restructured power market environment, under competition and open access, the different transactions can take place among buyers and sellers directly; these transactions are bilateral, multilateral and ancillary services transactions. Ref. [2] presents the study of methodology for calculation of the optimum size of a Wind system. The objective function considered in this paper is based on costs. The types and sizes of wind turbine generators (WTG), were calculated based on the minimum cost of system using GA. In [3] Unit sizing and cost analysis of stand-alone hybrid wind/PV/fuel cell power generation systems is presented. The Size optimization of a PV/wind hybrid energy conversion system with battery storage using simulated annealing is analysed in [4]. In this paper standalone mode is considered and the uncertainty of solar radiation and wind speed is not considered. Economic analysis of standalone and grid connected hybrid energy systems, is discussed in [5]. In this study evaluation of utilizing solar and wind energy with hydrogen as storage device to cover the electricity demand is investigated. The method of analysing in this paper is basically on costs of system and simulated using Homer software. Ref. [6] studied the Multi-objective design of PV-wind-diesel-hydrogenbattery systems. In this paper minimizing, simultaneously, the total cost throughout the useful life of the installation, 
pollutant emissions $\left(\mathrm{CO}_{2}\right)$ and unmet load are considered. Optimal sizing of hybrid wind/Photovoltaic/battery considering the uncertainty of wind and photovoltaic power using Monte Carlo have been studied in [7]. In mentioned research, a micro-grid consisting of hybrid wind/photovoltaic/battery in stand-alone mode based on cost optimization has been analysed. The hybrid model combines several features of the previous two models. In hybrid power market model, a lot of transactions are expected between buyers and sellers for more flexible and economic market operation. These transactions need to be evaluated ahead of their scheduling time to check their feasibility with respect to system operating conditions. Infeasible transactions can alter the economic schedule, cause congestion and threaten system security and stability of the network. Therefore the issue of DG optimal sizing in deregulated electricity market model needs to be addressed. In this paper, optimal sizing of wind turbines and battery in interconnected mode is described. Two main power sources, considered in this study for covering demand load of system, are main grid and wind turbines. The objective function is maximizing the total net present worth (NPW) of the active power generation system i.e. sum of net present of wind turbines-owners and distribution company over its 10year lifetime. With using Monte Carlo method uncertainty of wind power generation is considered. For probabilistic analysis of wind power generations, 15 years data of wind speed are used. The data has been used as every four-hour step. For every four-hour data, the best probability density function (PDF) of wind speed is determined. For a year, month and day Weibull distribution is known as suitable distribution for wind speed. This means that one year is separated to 2190 samples of wind speed and each fourhour sample has 15 samples of all 15 years, so the time step is four-hour. Using Monte Carlo and Particle Swarm Optimization (PSO), the best sizing of wind turbines is determined.

\section{Power flow equations and technical constraints}

Power flow equations corresponding to both active and reactive power balance for all the buses are expressed by the following equations [11]:

$$
\begin{aligned}
& P_{i}=\sum_{j=1}^{N b} V_{i} V_{j}\left[G_{i j} \cos \left(\delta_{i}-\delta_{j}\right)+B_{i j} \sin \left(\delta_{i}-\delta_{j}\right)\right] . \\
& Q_{i}=\sum_{j=1}^{N b} V_{i} V_{j}\left[G_{i j} \sin \left(\delta_{i}-\delta_{j}\right)-B_{i j} \cos \left(\delta_{i}-\delta_{j}\right)\right] .
\end{aligned}
$$

The equality constraints are, as follows.

Active and reactive power injections at bus- $i$ are expressed by the following equations:

$Q_{i}=Q_{g i}+\theta \cdot Q_{W T-i}-Q_{d i}$

$P_{i}=P_{g i}+\theta \cdot P_{W T-i}-\rho \cdot P_{d i}$.

where, $\rho$ indicates the demand variation factor. It represents the change in the operating point of the system. Also $\theta$ is decision variable with value $\{0,1\}$. In the presence of WT this value is equal to one and otherwise, it is zero. These constraints are power generation, voltage and angle limits, expressed by the following equations:

$$
\begin{aligned}
& P_{g i}^{\min } \leq P_{g i} \leq P_{g i}^{\max }, \\
& \delta_{i}^{\max } \leq \delta_{i} \leq \delta_{i}^{\max }, \\
& |V|_{i}^{\operatorname{mix}} \leq|V|_{i} \leq|V|_{i}^{\max }
\end{aligned}
$$

Other constrains that must be considered in this optimization are power flow direction and the capacity of feeders. Power flow direction is from upstream network, i.e. 63/20 substation to distribution system. So based on this constrain, the answers obtained from optimization procedures that do not satisfy this condition are eliminated from answers. Also using power flow for each of optimized answer the power line is calculated and compared with this limitation. These constrains are presented by (8).

$$
\left\{\begin{array}{l}
P_{\text {feeder }-i} \leq P_{i}^{\max } \\
0 \leq P_{\text {Sub.63/20 }}
\end{array} .\right.
$$

\section{Wind turbines (WTs)}

Wind turbines have been improved in technology in recent years so that their efficiency has been increased from $15 \%$ up to $50 \%$. It is notable that wind energy is one of the most important and promising sources of renewable energy. The main advantage of this energy source is the absence of harmful emissions and its economical efficiency. The wind turbine captures the wind's kinetic energy in rotor consisting of two or more blades mechanically coupled to an electrical generator. The turbine is mounted on tall tower to enhance the energy capture. The output power of wind turbines is predicted by using the following equation:

$$
\left\{\begin{array}{lr}
P_{w}=0 & \begin{array}{r}
v<v_{C I} \\
P_{w}=a v^{3}-b P_{r}
\end{array} \\
P_{w}=P_{r} & v_{C I}<v<v_{r} \\
P_{w}=0 & v>v_{C O}
\end{array} .\right.
$$

That the parameters $a$ and $b$ calculated as:

$$
\left\{\begin{array}{l}
a=p_{r} /\left(v_{r}^{3}-v_{C I}^{3}\right) \\
b=v_{C I}^{3} /\left(v_{r}^{3}-v_{C I}^{3}\right)
\end{array} .\right.
$$

In these equations: $P_{w}$ is the measurement power at the turbine, $P_{r}$ is the nominal power of turbine, $V_{r}$ is the speed related to nominal power, $V$ is the speed of wind, $V_{C I}$ is the low cut speed and $V_{C O}$ is the up cut speed. Fig. 1 shows the output power of wind turbine versus its speed. The turbine power versus wind speed curve for Generic $10 \mathrm{~kW}$ is plotted in Fig. 2. 


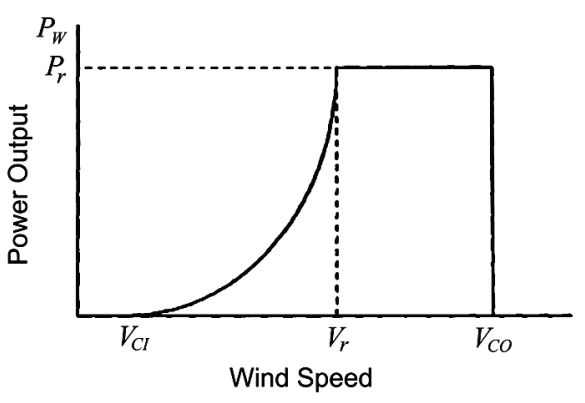

Figure1 Generation characterization of a wind turbine

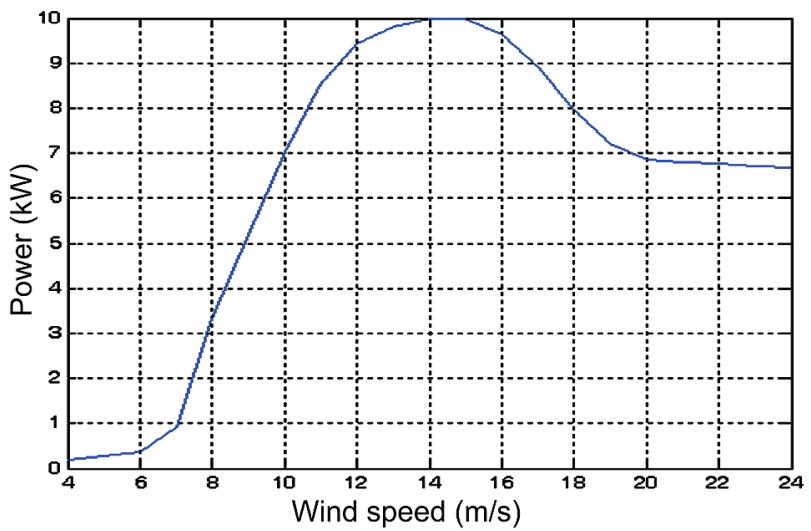

Figure $210 \mathrm{~kW}$ generic wind turbine power generation curve

\section{Economic analysis of system}

The net present worth, $(N P W)$ is the difference between present worth of benefit, $(P W B)$ and present worth of cost $(P W C)$ and expressed, as follows:

$$
N P W=P W B_{j}-P W C_{j} ; j=D I S C O, W F .
$$

The annualized cost is calculated by multiplying the total initial cost by the capital recovery factor $(C R F)$ and expressed, as follows:

$$
C_{\text {ann, tot }}=C_{\text {int }} \times C R F\left(i, R_{\text {proj }}\right),
$$

where, $C R F$ is given by the following equation:

$$
C R F\left(i, R_{\text {proj }}\right)=\frac{i(1+i)^{R_{\text {proj }}}}{(1+i)^{R_{\text {proj }}}-1},
$$

where, $R_{\text {proj }}$ is the project lifetime and $i$ is the annual interest rate and is related to the nominal interest rate by the following equation:

$i=\frac{i^{\prime}-f}{i^{\prime}+f}$

where $f$ is the inflation rate and $i^{\prime}$ is the nominal interest rate.

According to the proposed structure for distribution system, including WT units, the objective function is suggested, as follows:

Maximize:
$N P W=\omega_{1} \times N P W_{\mathrm{DISCO}}+N P W_{\mathrm{WT}-\mathrm{O} w n e r} \cdot$

With

$0 \leq w_{i} \leq 1$ and $\sum_{i=1}^{2} w_{i}=1$,

where $w_{1}$ and $w_{2}$ are weighting factors for DISCO (Distribution Company) and WT owners respectively.

$\boldsymbol{N P \boldsymbol { W }}$ is the Net Present Worth of the overall system. It includes the net present worth of DISCO and Wind turbine Owner. The Disco provides the necessary power of customers from the WT and Utility Grid. In fact, the main purpose is maximizing the net present worth of WT owner and DISCO. In this paper, PSO is used for the optimization procedure. In this section, all of the benefits and costs of DISCO and WT owners are presented.

\subsection{Income of DISCO}

The revenue of DISCO is the amount of monetary income received from selling electricity to customers (load), as follows [12]:

$$
R_{\mathrm{DISCO}}=\sum_{k=1}^{T} \sum_{i=1}^{M} P_{k, i, \mathrm{sell}}^{e} \times \rho_{k, i, \mathrm{sell}}^{e} .
$$

\subsection{Costs of DISCO}

The cost function for DISCO can be determined by the following equation [13]:

$$
C_{\mathrm{DISCO}}=C_{\mathrm{F}}+C_{\mathrm{S}-\mathrm{M} \& \mathrm{O}}+C_{\mathrm{Buy}} .
$$

Where the first term of (30) is the total cost of repairing and upgrading the network feeders and expressed by the following equation [13]:

$$
C_{\mathrm{F}}=\sum_{i=1}^{T N} \sum_{j=1}^{M} C_{i j} \sigma_{i j}
$$

The second term is the total cost of the maintenance and operation and repairing of substations expressed as follows [14]:

$$
C_{\mathrm{S}-\mathrm{M} \& \mathrm{O}}=\sum_{i=1}^{T N} \sum_{u=1}^{M} C_{i, u} \sigma_{i, u}+8760 \sum_{t=1}^{T} \beta\left(\sum_{i=1}^{T N} \sum_{u=1}^{T U i} C_{e} . P_{i, u}\right) .
$$

The last term is the total cost used for buying electricity from main grid, wind turbine owner in order to supply the local load, and it is expressed by the following equation [12]:

$C_{\mathrm{Buy}}=\sum_{k=1}^{T} P_{k, \mathrm{buy}}^{e, \mathrm{UP}} \rho_{k, \text { buy }}^{e, \mathrm{UP}}+\sum_{k=1}^{T} P_{k, \text { buy }}^{e, \mathrm{WT}} \rho_{k, \text { buy }}^{e, \mathrm{WT}}$.

It is notable that $\sigma_{i, u}$ and $\sigma_{i, j}$ are decision variables for the 
repair. It is equal to one in case of repair, otherwise it is zero.

\subsection{Income of wind turbine owner}

The revenue of wind turbine owner is the amount of the monetary income received from selling electricity to DISCO on peak. It is expressed by the following equation [12]:

$R_{\mathrm{WT}}=\sum_{k=1}^{T} \sum_{i=1}^{N_{\mathrm{DG}}} P_{k, i, \mathrm{sell}}^{e, \mathrm{WT}} \times \rho_{k, \mathrm{sell}}^{e, \mathrm{WT}}$.

\subsection{Costs of wind turbine owner}

The cost function for wind turbine owner can be calculated by the following equation [14]:

$C_{\mathrm{WT}}=C_{\mathrm{r} \& \mathrm{~m}}+C_{\mathrm{P}(\mathrm{WT})}$.

The first term is the repair and maintenance cost and expressed by the following equation [14]:

$$
C_{\mathrm{r} \& \mathrm{~m}}=8760 \sum_{i=}^{T} \beta \sum_{i=1}^{M}\left(C_{\mathrm{r} \& \mathrm{~m}} \cdot p f \cdot S_{\mathrm{DG}, i}\right) .
$$

The second term is the production cost. It is considered as a quadratic function of produced power, as follows [15]:

$$
C_{\mathrm{P}(\mathrm{WT})}=\sum_{i=1}^{N_{\mathrm{WT}}} C_{\mathrm{WT}, i},
$$

Where $C_{\mathrm{WT}}$, represents the generation cost of wind turbines and it is determined as follows [16]:

$$
C_{\mathrm{WT}, i}=a^{\prime}+b^{\prime} \times P_{\mathrm{WT}, i} .
$$

\section{Proposed method}

In this research, the numbers of wind turbine and battery are obtained and optimized for supplying the load. Maximization of Net Present Worth is considered as objective function and satisfies defined pool market indices as constrain. Uncertainty in power output of wind turbine is also considered. The algorithm of presented method is represented in Fig. 3.

\subsection{Monte Carlo method}

Monte Carlo method is a set of computational algorithms based on repeated random sampling to subtract their results. The Monte Carlo method is a broadly used apparatus in various courses, counting engineering, finance, biology, computer graphics, physics, chemistry, operations research and management science [17]. Monte Carlo approach works as a pattern described as follows:

1) Determination the boundary of data.

2) Data generation from probability distribution of input.

3) Deterministic calculation on the data

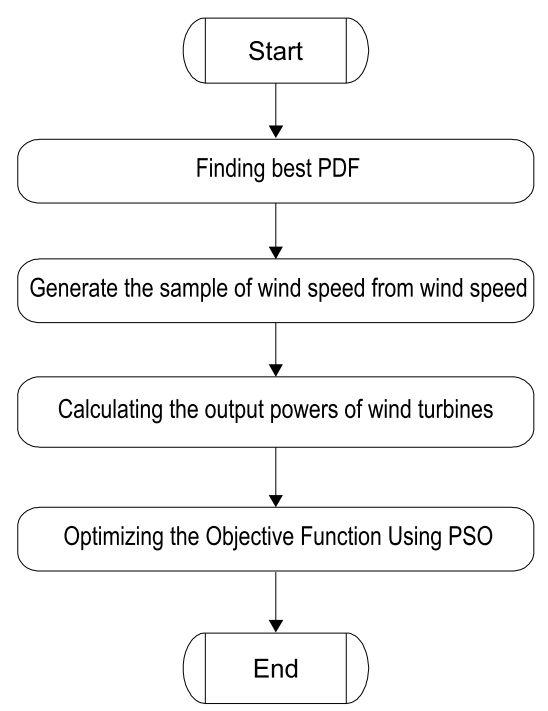

Figure 3 The algorithm of presented

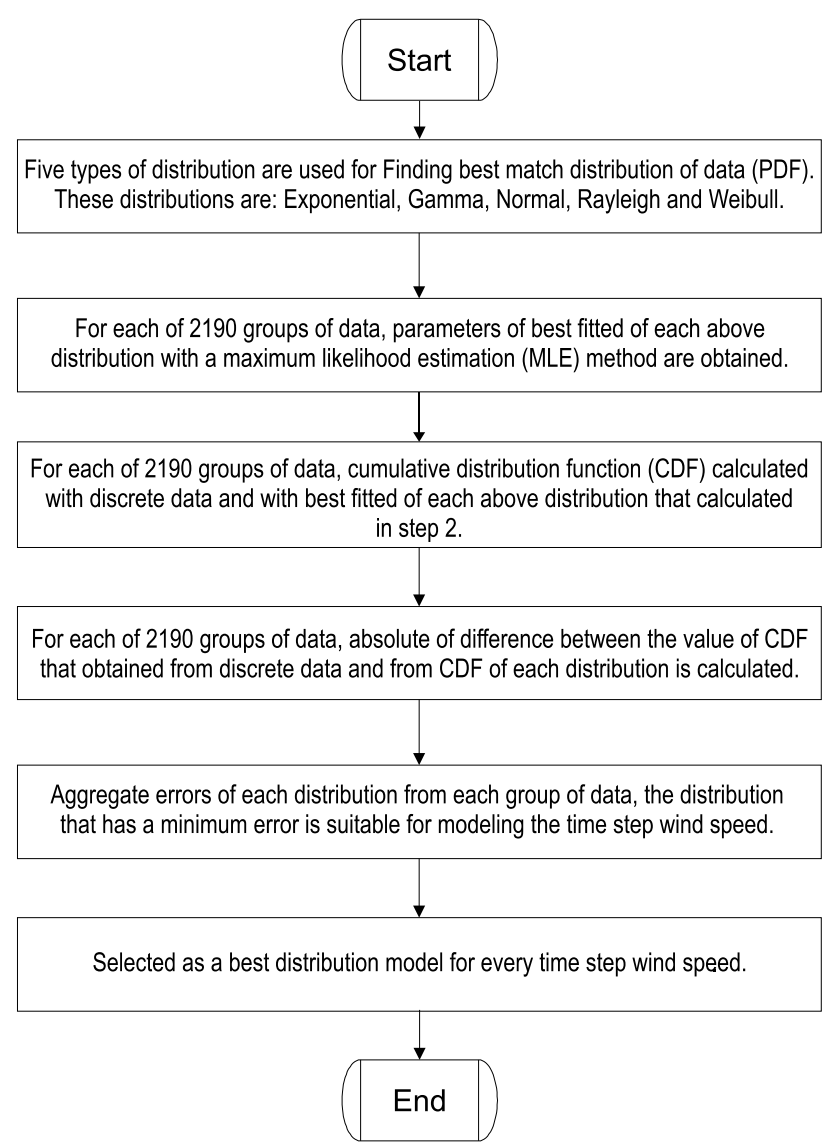

Figure 4 The algorithm of finding the suitable and best distribution for each time step wind speed

\subsection{Best distribution of wind speed}

In order to clarify the best probability density functions (PDF) of wind speed, 15 years data are used. The data has been used as every four-hour period. This means that one year is separated to 2190 samples of wind speed and each four-hour sample has 15 samples of all 15 years, so the time step is four-hour. The purpose is getting the PDF model for every four-hour of solar radiation. In order to compute the PDF for wind speed, various 
representations of wind speed for a year, month and day are investigated. For a year, month and day Weibull distribution is known as suitable distribution for wind speed. In this research, a distribution style for every time step wind speed data is considered, that for each time step the parameters of distribution are different from other hours. The algorithm of getting the most suitable distribution for each time step wind speed is shown in Fig. 4.

In this paper, PSO is considered as optimization algorithm.

\subsection{PSO-based optimization method}

In a PSO system, Birds' (particles) flocking optimizes a certain objective function. Each particle knows its current optimal position (pbest), which is an analogy of personal experiences of each particle. Each particle also knows the current global optimal position (gbest) among all particles in the population. Through specific equations, each particle adjusts its position and determines the search direction according to its search memory and those of others [18].

Using the PSO, the velocity can be represented under Eq. (27) in the PSO algorithm. Using Eq. (26), a certain velocity can be calculated as the position of individuals gradually moves closer to pbest and gbest. The current position can be modified by:

$$
\begin{aligned}
& v_{i, d}^{j+1}=K \times\left[\begin{array}{l}
v_{i, d}^{j}+c_{1} \times \operatorname{rand}(0,1) \times\left(\text { Xbest }_{i, d}^{j}-X_{i, d}^{j}\right) \\
+c_{2} \times \operatorname{rand}(0,1) \times\left(\text { Gbest }^{j}-x_{i, d}^{j}\right)
\end{array}\right], \\
& X_{i, d}^{j+1}=X_{i, d}^{j}+V_{i, d}^{j} .
\end{aligned}
$$

Where

$$
K=\frac{2}{\left|2-c-\sqrt{c^{2}-4 c}\right|}, \quad c=c_{1}+c_{2}>4
$$

$c_{1}, c_{2}$ is the acceleration constant, in this paper, $c_{1}=c_{2}$ $=4,05$.

\section{Simulation results}

In this paper, wind turbine and battery are considered for supplying the load. Pool-based power market is considered as constraints equation in optimization procedure in net present value of total system including distribution company and wind turbine owner.

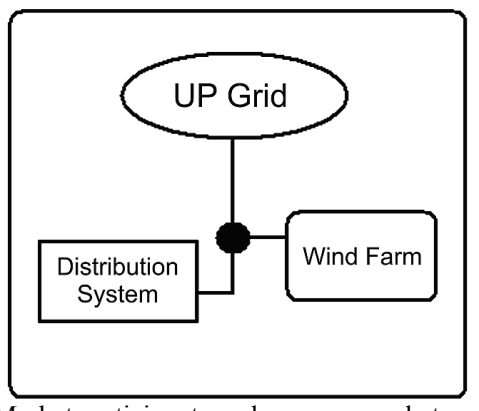

Figure 5 Market participants under power market environment
The power market considered in this research is shown in Fig. 5. In this market, multi participants including (1) UP grid=sub. 63/20, (2) Wind Farm as DG, (3) Distribution company (DISCO) are considered.

In this study the wind speed variation is considered as presented in Fig. 6. In order to consider the uncertainty of wind speed based on proposed method the histogram of power generated from a wind turbine for a time step of a year is shown in Fig. 7. Optimization algorithm run and the variables are updated in each time step.

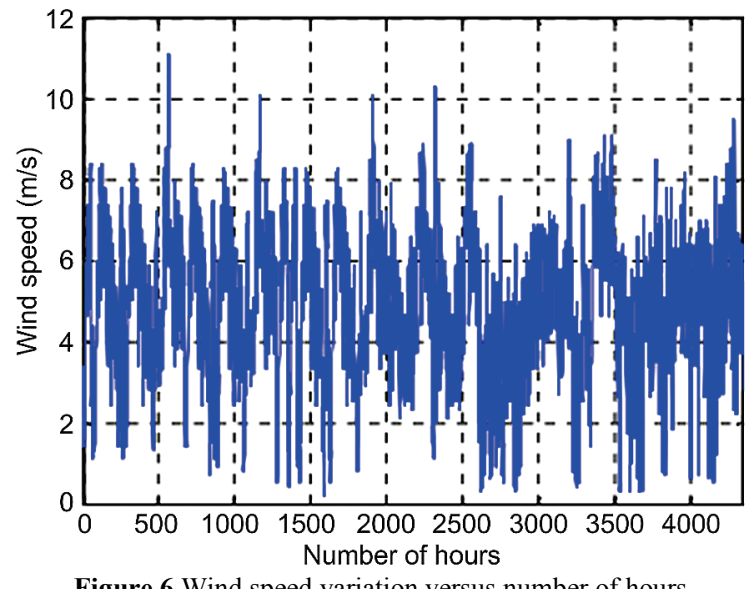

Figure 6 Wind speed variation versus number of hours

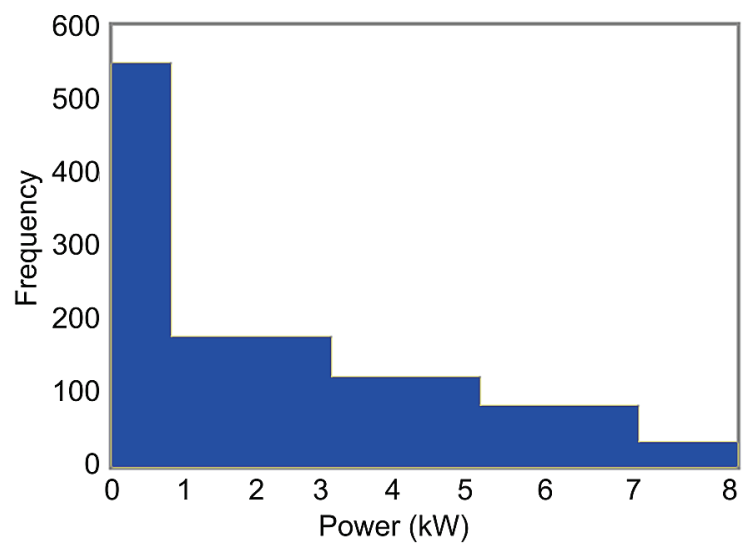

Figure 7 Histogram of a time step wind turbine power output

One of the conventional methods of solving this problem is lambda-iteration method but owing to tedious calculations and its inability to solve multi-modal and discontinuous problems, novel techniques have replaced it. The optimal cost of problem was found out to be 125185 \$ using lambda iteration method, while as shown in table 6 the optimal cost is calculated as $128911 \$$ and 125216 \$ using GA and PSO respectively.

As listed in Tab. 6, the PSO result for optimizing the total cost is closer to result of lambda iteration method. As shown in Tab. 1, a total of 380, 350 iterations respectively were required to converge to the optimal solution for the problem using GA and PSO respectively. The final computational time has been obtained by averaging the times for 1000 runs.

The test results show that PSO algorithm converges to optimal cost with reduced computational time when compared to GA.

In Tab. 2, the comparison of four mentioned optimization approaches for passive filter design problem from point of views accuracy, computational time and 
convergency speed are analysed.

Table 1 Comparison of iterations and computational time

\begin{tabular}{|c|c|c|c|}
\hline Method & Optimal cost (\$) & Iterations & $\begin{array}{c}\text { Computational time } \\
(\mathrm{ms})\end{array}$ \\
\hline GA & 128911 & 380 & 845 \\
\hline PSO & 125216 & 350 & 735 \\
\hline
\end{tabular}

Table 2 Evaluation of four optimization approaches

\begin{tabular}{|c|c|c|c|}
\hline Method & Accuracy & $\begin{array}{c}\text { Convergency } \\
\text { speed }\end{array}$ & $\begin{array}{c}\text { Computational } \\
\text { time }\end{array}$ \\
\hline GA & Good & Med & Med \\
\hline PSO & Good & Good & Med \\
\hline
\end{tabular}

Tab. 2 shows that the PSO with 2 Good and 1 Med score in comparison with GA with 1 Good and 2 Med score is the most suitable method to search the optimum solution. Therefore the analysis of system with 33 buses has been addressed using PSO method.

The PSO parameters used for this study are listed in Tab. 3.

Table 3 The PSO parameters used for this study

\begin{tabular}{|c|c|}
\hline Indices & Parameter value \\
\hline Num. of particles (d) & 500 \\
\hline $\mathrm{C}_{1}, \mathrm{C}_{2}$ & 5 \\
\hline$W_{\max }, W_{\min }$ & 5,5 \\
\hline No. of iteration & 500 \\
\hline$V_{q d}^{\min }, V_{q d}^{\max }$ & $-0,5 q_{d}, 6 q_{d}^{\max }$ \\
\hline
\end{tabular}

For wind turbines resources units, for selling power to Disco, two prices are considered in off-peak and peak periods. These periods are listed in Tab.4.

Table 4 Different periods for each energy resources units in wind farm

Table 4 Different periods for each energy resources units in wind farm
\begin{tabular}{|c|c|c|c|}
\hline Type & $\begin{array}{c}\mathrm{C}_{\mathrm{MG}}(\mathrm{min}) \\
\text { off-peak }\end{array}$ & $\begin{array}{c}\mathrm{C}_{\mathrm{MG}}(\mathrm{min}) \\
\text { on-peak }\end{array}$ & $\begin{array}{c}\mathrm{C}_{\mathrm{MG}}(\max ) \\
\text { for all times }\end{array}$ \\
\hline Price $(\$ / \mathrm{kW} \cdot \mathrm{h})$ & 0,06 & 0,065 & 0,12 \\
\hline
\end{tabular}

Also, the demand power is considered according to different pattern loads as given in Tab.5.

Table 5 Different pattern load

\begin{tabular}{|c|c|c|c|c|}
\hline Table 5 Different pattern load \\
\hline Load profile & Low & Medium & Peak & High Peak \\
\hline $\begin{array}{c}\text { Demanded } \\
\text { power (kW) }\end{array}$ & 800 & 1000 & 1200 & 1400 \\
\hline Load duration & 6 & 10 & 5 & 3 \\
\hline
\end{tabular}

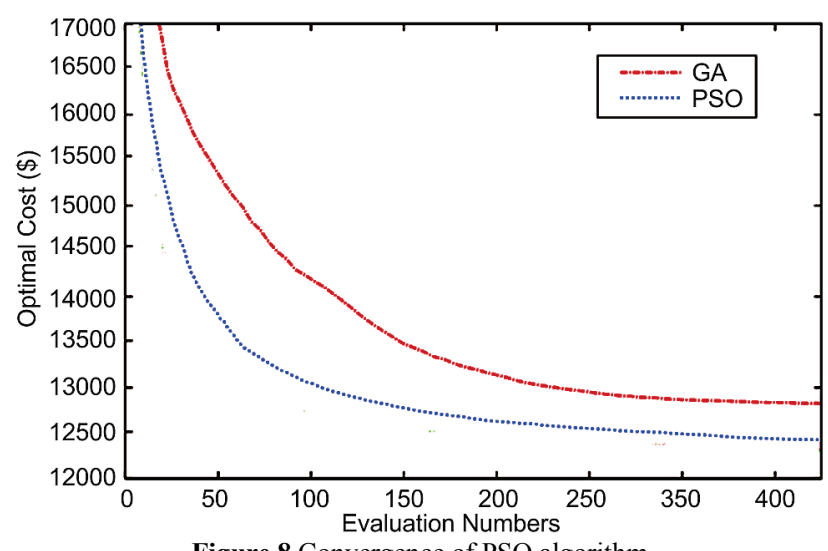

Figure 8 Convergence of PSO algorithm

The convergence of PSO versus GA algorithm is shown in Fig. 8 and the best combination of wind turbine and battery units with optimized net present worth are listed in Tabs 6 . and 7.

Table 6 Optimal prices for WT Owner and DISCO under pool electricity market

\begin{tabular}{|c|c|c|c|}
\hline Case & NPW_WT & NPW_DISCO & NPW_Total \\
\hline $\begin{array}{c}\text { Uniform } \\
\text { pricing }\end{array}$ & $32391 \$$ & $218526 \$$ & $301203 \$$ \\
\hline $\begin{array}{c}\text { Pay as bid } \\
\text { pricing }\end{array}$ & $31465 \$$ & $205626 \$$ & $306093 \$$ \\
\hline
\end{tabular}

Table 7 Optimal number for WT units and battery under pool electricity

\begin{tabular}{|c|c|c|c|}
\hline market \\
\hline Case & Cost & WT num. & Batt. num. \\
\hline Uniform pricing & 202611 & 209 & 17 \\
\hline Pay as bid pricing & 212920 & 212 & 14 \\
\hline
\end{tabular}

Operation of wind turbines under various strategies of pool market policies, gives optimal prices for selling power to Disco with optimal exchange power between Wind Turbines Owners and Disco, as well as between Upstream Network (63/20 substation) and Disco. The simulation results of optimal power and price exchanged between upstream network, wind farms and Disco during peak and off-peak with considering wind speed uncertainty are listed in Tab. 8 .

Table 8 Optimal exchanged powers and prices for wind farm during peak and off-peak

\begin{tabular}{|c|c|c|c|c|}
\hline Case & $\begin{array}{c}\text { PWT(kW) } \\
\text { on-peak }\end{array}$ & $\begin{array}{c}\text { PWT(kW) } \\
\text { off-peak }\end{array}$ & $\begin{array}{c}\mathrm{CWT}(\$ / \mathrm{kW} \cdot \mathrm{h}) \\
\text { on-peak }\end{array}$ & $\begin{array}{c}\mathrm{CWT}(\$ / \mathrm{kW} \cdot \mathrm{h}) \\
\text { off-peak }\end{array}$ \\
\hline $\begin{array}{c}\text { Uniform } \\
\text { pricing }\end{array}$ & 730 & 1100 & 0,066 & 0,059 \\
\hline $\begin{array}{c}\text { Pay as bid } \\
\text { pricing }\end{array}$ & 840 & 1089 & 0,065 & 0,062 \\
\hline
\end{tabular}

\section{Conclusion}

This paper presents a multi-objective function in presence of technical, economical and power market constraints for optimal operation of wind turbines in distribution systems in order to maximize total net present worth of system. Two basic power sources, considered in this study for covering demand power, are upstream network i.e. $63 \mathrm{kV} / 20 \mathrm{kV}$ substation and distributed generations from kind of wind turbines. The objective function consists of net present worth of distribution company (Disco) and net present worth of wind turbines owners (WT-Owner). In this paper the Monte Carlo technique is used for considering uncertainty of wind speed. The implemented technique relies on PSO and weight coefficient method (WCM). Simulation results on 33-bus distribution test system under pool power market operation are presented to show the effectiveness of the proposed approach. In order to clarify the best probability density functions (PDF) of wind speed, 15 years data are used. The data have been used as every four-hour period. This means that one year is separated to 2190 samples of wind speed and each four-hour sample has 15 samples of all 15 years, so the time step is four-hour. The purpose is getting the PDF model for every four-hour of wind speed. In order to compute the PDF for wind speed, various representations of wind speed for a year, month and day are investigated. For a year, month and day Weibull distribution is known as suitable distribution for wind speed. In this research, a distribution style for every time step wind speed data is considered, that for each time step 
the parameters of distribution are different from other hours.

\section{References}

[1] Stacke, F.; Cuervo, P. Integrated pool/bilateral/reserve market operation under pay-as-bid pricing. // Proceeding of the $5^{\text {th }}$ International Conference on the European Electricity Market. 23, 4(2008), pp. 1-8.

[2] Benatiallah, A.; Kadi, L.; Dakyo, B. Modeling and Optimization of Wind Energy Systems. // Jordan Journal of Mechanical and Industrial Engineering. 4, 1(2010).

[3] Nelson, D. B.; Nehrir, M. H.; Wang, C. Unit sizing and cost analysis of stand-alone hybrid wind/PV/fuel cell power generation systems. // Renewable Energy. 31, (2006), pp. 1641-1656.

[4] Ekrena, O.; Ekren, B. Y. Size optimization of a PV/wind hybrid energy conversion system with battery storage using simulated annealing. // Applied Energy. 87, (2010), pp. 592-598.

[5] Türkay, B. E.; Telli, A. Y. Economic analysis of standalone and grid connected hybrid energy systems. // Renewable Energy. 36, (2011), pp. 1931-1943.

[6] Dufo-Lopez, R.; Bernal-Agustin, J. L. Multi-objective design of PV - wind - diesel - hydrogen - battery systems. // Renewable Energy. 33, (2008), pp. 2559-2572.

[7] Skoulidas, C. C.; Vournas, C. D.; Papavassilopoulos, G. P. An Adaptive Game for Pay-as-Bid and Uniform Pricing power Pools Comparison. $/ / 3^{\text {rd }}$ Mediterranean Conference and Exhibition on Power Generation, Transmission, Distributions and Energy Conversion, MED Power 2002, Athens Greece, November 4-6, 2002.

[8] Tierney, S.; Schatzki, T.; Mukerji, R. Uniform-Pricing versus Pay-as-Bid in Wholesale Electricity Markets: Does it make a difference? New York ISO, March 2008.

[9] Kockar, I.; Franco, P. C.; Galiana, F. D. Pay as Bid Pricing in Combined Pool / Bilateral Electricity Markets. // $14^{\mathrm{rd}}$ PSCC, Sevilla, 24-28 June 2002.

[10] Kumar, A.; Gao, W. Optimal distributed generation location using mixed integer non-linear programming in hybrid electricity markets. // IET Gener. Transm. Distrib. 4, 2(2010), pp. 281-298.

[11] Bagherian, A.; Tafreshi, S. M. M. A developed energy management system for a microgrid in the completive electricity market. // IEEE Bucharest Power Teach Conference, Bicharest, Romania, Jun $28^{\text {th }}-$ July $2^{\text {nd }}, 2009$, pp. 1-6.

[12] Chandramohan, S.; Atturulu, Naresh; Kumudini Devi, R. P.; Venkatesh, B. Operating cost minimization of a radial distribution system in a deregulated electricity market through re-configuration using NSGA method. // Int J Electr Power Energy Syst. 32, (2010), pp. 126-132.

[13] Mantway, A. H.; Al-Muhaini, Md. M. Multi-Objective BPSO algorithm for distribution system expansion planning including distributed generation. // Transmission and Distribution Conference and Exposition, IEEE/PES, Chicago, IL, 21-24 April, 2008, pp. 1-8.

[14] Mohamed, F. A.; Koivo, H. N. System modelling and online optimal management of Micro-Grid using Mesh Adaptive Direct Search. // International Journal of Electrical Power \& Energy Systems. 32, 5(2010), pp. 398407.

[15] Niknama, T.; Kavousifarda, A.; Tabatabaei, S.; Aghaei, J. Optimal operation management of fuel cell/wind/ photovoltaic power sources connected to distribution networks. // Journal of Power Sources. 196, (2011), pp. 8881-8896.

[16] Billinton, R.; Allan, R. N. Reliability Evaluation of Power Systems, Second Edition, Aug 31, 1996.
[17] Angeline, P. Using selection to improve particle swarm optimization. // Proceeding of IEEE international conference on evolutionary computation (ICEC), Anchorage, May, 1998.

[18] Yoshida, H.; Kawata, K.; Fukuyama, Y.; Takayama, S.; Nakanishi, Y. A particles swarm Optimization for reactive power and voltage control considering voltage security assessment. // IEEE Trans Power Syst. 15, 4(2000), pp. 1232-1239.

\section{Nomenclature}

$P_{i}, Q_{i} \quad$ Net power injected at each buses of system

$P g_{i}, Q g_{i} \quad$ Power injected at each bus from sub. 63/20

$P_{\mathrm{WT} i}, Q_{\mathrm{WT} i}$ Active and reactive power injected at each bus from wind farm

$P_{d i}, Q_{d i} \quad$ Demand active and reactive power at each buses of system

$P_{k, \mathrm{sel} l}^{e} \quad$ Amount of electricity buying from main grid at year $k$

$\rho_{k, \text { sell }}^{e} \quad$ Price of electricity buying from main grid at year $k$

$M \quad$ Total number of system load buses

$T N \quad$ Total number of system buses

$T U_{i} \quad$ Total number of substation transformers in distribution system

$\sigma_{i, u} \quad$ Transformer $u$ in substation $i$ decision variable for repair

$\sigma_{i, j} \quad$ Feeder $i$ to $j$ binary decision variable for repair

$C_{i, j} \quad$ Total repair and maintenance cost of feeder $i$ to $j(\$ / \mathrm{km})$

$C_{i, u} \quad$ Total repair and maintenance cost of transformer $u$ in substation $i$

$C_{e} \quad$ Electricity market price $(\mathrm{S} / \mathrm{kW} \cdot \mathrm{h})$

$P_{i, u} \quad$ Transformer u in substation I dispatched power $(\mathrm{kW})$

$P_{k \text {,buy }}^{e, \text { bu }} \quad$ Amount of electricity buying from main grid at year $k$

$\rho_{k \text {,buy }}^{e, \text { PP }} \quad$ Pricing of electricity buying from main grid at year $k$

$P_{k, \text { buy }}^{e, \mathrm{WF}}$ Amount of electricity buying from WF at year $k$

$\rho_{k, \text { buy }}^{e, \mathrm{WF}}$ Pricing of electricity buying from WF at year $k$

$\beta \quad$ Present worth factor

$T$ Lifetime of project

pf System power factor

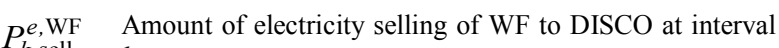

$k$,sell $k$

$\rho_{k, \text { sell }}^{e, \mathrm{WF}} \quad$ Pricing of electricity selling of WF to DISCO at interval $k$

$P_{\mathrm{WF}} \quad$ Power of wind farm.

\section{Authors' addresses}

\section{Mohammadi}

Department of Electrical Engineering,

Borujerd Branch, Islamic Azad University,

Borujerd, Iran

E-mail: mohamadi.m@iaub.ac.ir

\section{H. Nasiraghdam}

Department of Electrical Engineering,

Ahar Branch, Islamic Azad University,

Ahar, Iran

E-mail: h.nasiraghdam@iau-ahar.ac.ir 